\title{
Bacteriological quality of raw milk marketed in and around Guwahati city, Assam, India
}

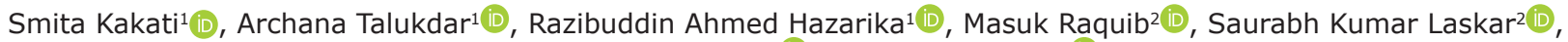
Girindra Kumar Saikia ${ }^{3}$ (I) and Zakir Hussein ${ }^{4}$ (D)

1. Department of Veterinary Public Health, College of Veterinary Science, Assam Agricultural University, Khanapara, Guwahati, Assam, India; 2. Department of Livestock Products Technology, College of Veterinary Science, Assam Agricultural University, Khanapara, Guwahati, Assam, India; 3. Department of Microbiology, College of Veterinary Science, Assam Agricultural University, Khanapara, Guwahati, Assam, India; 4. Department of Livestock Production and Management, College of Veterinary Science, Assam Agricultural University, Khanapara, Guwahati, Assam, India.

Corresponding author: Masuk Raquib, e-mail: masuk.raquib@aau.ac.in

Co-authors: SK: kakatismita89@gmail.com AT: archiivet@rediffmail.com, RAH: rah1962@rediffmail.com, SKL: saurabhlaskar@gmail.com, GKS: saikiagk@yahoo.com, ZH: drjakir@gmail.com

Received: 05-07-2020, Accepted: 18-01-2021, Published online: 18-03-2021

doi: www.doi.org/10.14202/vetworld.2021.656-660 How to cite this article: Kakati S, Talukdar A, Hazarika RA, Raquib M, Laskar SK, Saikia GK, Hussein Z (2021) Bacteriological quality of raw milk marketed in and around Guwahati city, Assam, India, Veterinary World, 14(3): 656-660.

\begin{abstract}
Background and Aim: Milk is a highly perishable commodity, which is subjected to various types of contamination right from the farm level to the consumers' table. This study aimed to assess the quality of raw milk sold in and around Guwahati city based on the microbial load.

Materials and Methods: A total of 200 raw pooled milk samples collected from 25 different locations in and around Guwahati city were subjected to quality evaluation based on the methylene blue reduction test (MBRT), standard plate count, and coliform count as per the standard procedure.

Results: Out of the 200 samples evaluated, more than $50 \%$ of them were graded as poor to very poor quality based on the MBRT results. None of the samples could be graded as excellent quality and only $14.5 \%$ were graded as good quality. The standard plate count and coliform count of all the raw milk samples were found to be significantly higher than the legal standard. A highly significant $(\mathrm{p}<0.01)$ difference was observed for standard plate count and coliform count among the different locations in and around Guwahati city.
\end{abstract}

Conclusion: From the present study, it could be inferred that raw milk sold in most parts of Guwahati city do not confer to the legal microbiological standard and may pose a high risk of milk-borne illness among consumers of the city, which needs a systematic series of actions to be implemented properly.

Keywords: coliform count, methylene blue reduction test, raw milk, total viable count.

\section{Introduction}

Milk, in its natural form, is a unique food that provides nourishment to human beings since ages. It provides immunogenic protection and supplies nutrients, such as proteins, fat, carbohydrates, vitamins, and minerals, in an easily digestible form than any other single food [1]. There has been an increase in milk consumption in the developing countries, including India and the trend is likely to continue as the demand for animal-source food has shown a rising trend due to population growth, changing lifestyles, increasing wealth, and increasing dependence of large vegetarian population on dairy products for proteins and other micronutrients $[2,3]$.

In recent times, there is an apparently growing concern regarding the safety and health and

Copyright: Kakati, et al. Open Access. This article is distributed under the terms of the Creative Commons Attribution 4.0 International License (http://creativecommons.org/licenses/by/4.0/), which permits unrestricted use, distribution, and reproduction in any medium, provided you give appropriate credit to the original author(s) and the source, provide a link to the Creative Commons license, and indicate if changes were made. The Creative Commons Public Domain Dedication waiver (http://creativecommons.org/ publicdomain/zero/1.0/) applies to the data made available in this article, unless otherwise stated. nutritional benefits of milk and dairy products among both urban and rural consumers. Milk being a perishable commodity is highly vulnerable to bacterial contamination as it provides a favorable medium for its growth. Today's consumers need clean, wholesome, and nutritious food that is produced and processed in a sound, sanitary condition and are free from pathogens. Milk passes through different handlers from the farm to the table of consumers and failure to maintain cold chain may result in poor quality of milk. Raw, poorly processed and inefficiently handled milk and milk products can lead to severe food-borne illness in humans [4]. Particularly in developing countries, the shelf-life of milk and milk products tends to be shorter as the production of milk and its processing into different milk products takes place under unsanitary conditions and poor production practices [5]. Coliforms are invariably found in raw milk but with good manufacturing practices, their number can be kept very low [6]. Their presence is an indication of unsanitary production practices and/or improper handling of either milk or milk utensils [7]. Even pasteurized milk may have a high bacterial load which may be attributed to defective pasteurization 
machinery, microbes surviving in pasteurization, and post-pasteurized contamination due to poor processing and handling conditions and/or poor hygienic practices followed by the workers [8].

Guwahati, the capital city of Assam (24 $44^{\prime}$ 'to $27^{\circ} 45^{\prime} \mathrm{N}$ latitude; $89^{\circ} 41^{\prime}$ to $96^{\circ} 2^{\prime} \mathrm{E}$ longitude), India, is the gateway of Northeast India. There is a good demand for quality milk and safe milk products in and around the city. However, limited work has been undertaken so far on the assessment of microbial load in raw milk. Considering the importance of safe food to consumers, the present study was envisaged to determine the microbial load in raw milk marketed in and around Guwahati city.

\section{Materials and Methods}

\section{Ethical approval}

The research was approved by the Institutional Animal Ethics Committee of Faculty of Veterinary Science, Assam Agricultural University (AAU), Khanapara (770/ac/CPCSEA/FVSc/AAU/IAEC/1516/352) dated 10.04.2015.

\section{Study location and period}

The work was carried out in the Department of Veterinary Public Health, Department of Livestock Products Technology, and Department of Veterinary Microbiology, College of Veterinary Science, AAU, Khanapara, Guwahati, India, from June 2015 to May 2016.

\section{Sampling}

Two hundred raw pooled milk samples (approximately $200 \mathrm{~mL}$ ) were collected aseptically in sterile containers from bulk milk cans from 25 different locations and markets in and around Guwahati city, as mentioned in Table-1. The samples were transported immediately to the laboratory, maintaining the cold chain and thereafter subjected to bacteriological examination within 3-4 h of collection.

\section{Methylene blue reduction test (MBRT)}

The MBRT was carried out as per the standard method [9]. One milliliter of methylene blue (1:2500) was added to $10 \mathrm{~mL}$ of milk in a sterilized test tube followed by sealing it with a rubber stopper and slowly inverted it 3 times to mix the content thoroughly. The tube was then placed in a water bath maintained at $35^{\circ} \mathrm{C}$ and examined at regular intervals up to $8 \mathrm{~h}$. Time taken for the sample to decolorize, that is, reduction time, was noted based on the time taken by dye from a definite color (blue) to colorless form (white), and the result was interpreted. The quality of milk was graded as excellent (no decolorization within $8 \mathrm{~h}$ ), good (decolorization between 5 to and $8 \mathrm{~h}$ ), fair (decolorization between 2 to and $5 \mathrm{~h}$ ), poor (decolorization between $20 \mathrm{~min}$ and $2 \mathrm{~h}$ ), and very poor (decolorization in $<20 \mathrm{~min}$ ), respectively.

\section{Total viable count (TVC) and coliform count}

The TVC of the milk samples was performed by the pour plate technique [10]. Serial 10-fold dilutions were done in a sterilized normal saline solution and appropriate dilution was transferred into the sterilized Petri dishes in duplicates. Twenty milliliters of pre-sterilized, molten, and cooled plate count agar medium for TVC and violet red bile agar medium for coliform count were poured into the respective Petri dishes. The inoculum was mixed thoroughly with the media by rotating the plates several times in clockwise and anti-clockwise directions. After solidification, the plates were incubated at $37^{\circ} \mathrm{C}$ and $35^{\circ} \mathrm{C}$, respectively, for 24-48 h. Colonies grown in respective media were counted and the counts were expressed as $\log _{10} \mathrm{cfu} / \mathrm{mL}$ of sample. Coliform organisms were confirmed based on the colony characteristics and production of gas in Brilliant Green Lactose Broth (BGLB) incubated at $35^{\circ} \mathrm{C}$ for $24-48 \mathrm{~h}$.

\section{Statistical analysis}

The data of the present study were statistically analyzed using SPSS version-20.0 software (IBM Corp., Armonk, NY, USA). One-way analysis of variance was performed for different parameters and means were compared by Duncan's multiple range test with $1 \%$ and $5 \%$ significance level.

\section{Results and Discussion MBRT}

The results of MBRT of the raw milk samples collected from 25 different locations in and around Guwahati city are presented in Figure-1. None of the samples could be graded as excellent quality, while, based on the time required to reduce the dye to colorless form, only $14.5 \%$ could reduce the dye between 5 and $8 \mathrm{~h}$ and were graded as good quality. Out of the 200 pooled milk samples, $31 \%$ of the samples could

Table-1: Different collection points of milk samples in and around Guwahati city.

\begin{tabular}{lclcc}
\hline Place of collection & $\begin{array}{c}\text { Number of } \\
\text { samples }\end{array}$ & Place of collection & $\begin{array}{c}\text { Number of } \\
\text { samples }\end{array}$ & $\begin{array}{c}\text { Place of collection } \\
\text { samples }\end{array}$ \\
\hline Bamunimaidan & 08 & Jorabat & 08 & Panjabari \\
Basistha & 08 & Kahilipara & 08 & Satgaon \\
Bonda & 08 & Kalapani & 08 & Six Mile \\
Chandmari & 08 & Khanapara & 08 & Ten Mile \\
Eight Mile & 08 & Maligaon & 08 & Ulubari \\
Ganeshguri & 08 & Mathghoria & 08 & Bhetapara \\
Hatigaon & 08 & Nine Mile & 08 & Zoo Road Tiniali \\
Jalukbari & 08 & Noonmati & 08 & 08 \\
Jonali & 08 & Panikhaiti & 08 & 08 \\
\hline
\end{tabular}




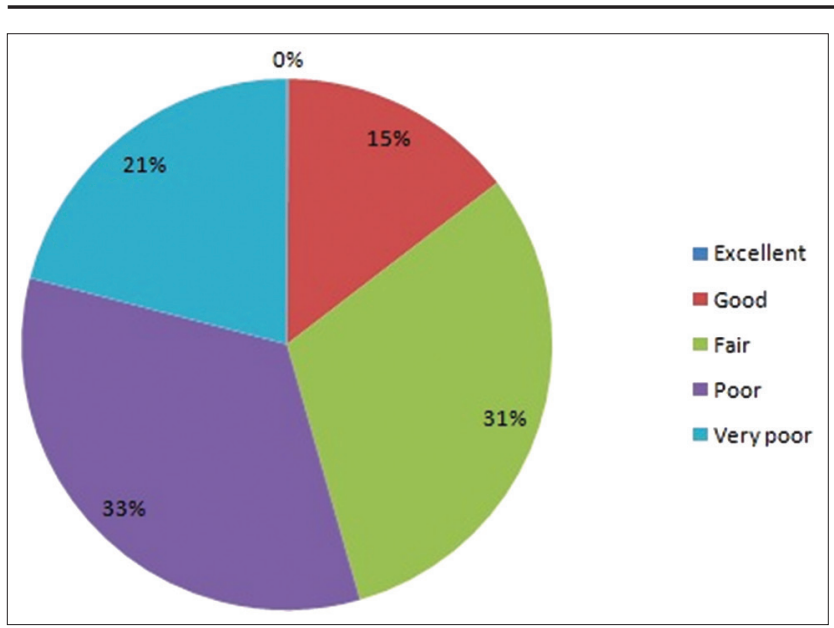

Figure-1: Percentage contribution of different grades of milk samples in methylene blue reduction test.

reduce the dye between 2 and $5 \mathrm{~h}$ and graded as fair, $33.5 \%$ as poor (dye reduction time $20 \mathrm{~min}-2 \mathrm{~h}$ ), followed by $21 \%$ as very poor quality (dye reduction time $<20 \mathrm{~min}$ ), respectively, irrespective of their locations with the highest percentage graded as poor quality. It could be assessed from the present study that most of the milk sold in and around Guwahati might have a poor shelf-life unless adequate intervention measures for processing are adopted at the earliest. The variation in the grading of milk samples collected from 25 different locations might be due to location specificity, seasonal variation, unhygienic production practices, inadequate maintenance of cold chain, milk composition, and initial contamination [11-15].

\section{Bacteriological analysis} TVC

The details of the TVC of raw milk samples collected from 25 different locations in and around Guwahati city are presented in Table-2. Analysis of variance revealed a highly significant difference $(p<0.01)$ among the different locations in and around the city. From the results, it could be inferred that the microbial load in 8 mile area $\left(14.62 \pm 0.25 \log _{10} \mathrm{cfu} /\right.$ $\mathrm{mL})$ was found to be significantly higher $(\mathrm{p}<0.01)$ compared to the samples collected from other locations, thus indicating a high level of microbial contamination. On the contrary, the lowest microbial load was observed in raw milk samples collected from Maligaon area $\left(10.59 \pm 0.07 \log _{10} \mathrm{cfu} / \mathrm{mL}\right)$. However, it did not differ significantly from Bamunimaidan, Panjabari, Hatigaon, Ganeshguri, and Satgaon area, respectively, while for the rest of the locations, the TVC was found to be highly significant $(p<0.01)$. This might probably be due to high count in the raw milk due to contamination, high ambient temperature, unable to maintain cold chain during transportation, and poor and unhygienic milking practices. The samples collected from Jorabat area were found to have significantly lower microbial load $(\mathrm{p}<0.01)$ than 8 mile area and could be adjusted as the second most contaminated milk sold in that particular area. In the
Table-2: Total viable count $\left(\log _{10} \mathrm{cfu} / \mathrm{mL}\right)$ of raw milk samples collected from different locations.

\begin{tabular}{lc}
\hline Location & Mean \pm SE \\
\hline Zoo Road Tiniali & $11.27 \pm 0.14^{\mathrm{jklmn}}$ \\
Bamunimaidan & $11.02 \pm 0.10^{\mathrm{Imnop}}$ \\
Bonda & $11.19 \pm 0.10^{\mathrm{klmno}}$ \\
Maligaon & $10.59 \pm 0.07^{\mathrm{p}}$ \\
Panjabari & $11.002 \pm 0.06^{\mathrm{mnnop}}$ \\
Eight mile & $14.62 \pm 0.25^{\mathrm{a}}$ \\
Basistha & $11.36 \pm 0.10^{\mathrm{jklm}}$ \\
Hatigaon & $10.82 \pm 0.07^{\mathrm{nop}}$ \\
Jalukbari & $11.41 \pm 0.12^{\mathrm{ijkl}}$ \\
Jonali & $11.16 \pm 0.14^{\mathrm{klmno}}$ \\
Jorabat & $13.85 \pm 0.37^{\mathrm{b}}$ \\
Khanapara & $12.96 \pm 0.20^{\mathrm{cd}}$ \\
Kahilipara & $11.34 \pm 0.09^{\mathrm{jklm}}$ \\
Mathghoria & $11.97 \pm 0.08^{\mathrm{fgh}}$ \\
Ganeshguri & $10.90 \pm 0.09^{\mathrm{mnop}}$ \\
Paltanbazar & $13.22 \pm 0.27^{\mathrm{c}}$ \\
Ulubari & $12.05 \pm 0.23^{\mathrm{fg}}$ \\
Bhetapara & $12.33 \pm 0.13^{\mathrm{ef}}$ \\
Satgaon & $10.74 \pm 0.06^{\mathrm{op}}$ \\
Chandmari & $12.63 \pm 0.28^{\mathrm{de}}$ \\
Panikhaiti & $11.70 \pm 0.20^{\mathrm{ghij}}$ \\
Nine mile & $11.52 \pm 0.14^{\mathrm{hijk}}$ \\
Six mile & $13.27 \pm 0.25^{\mathrm{c}}$ \\
Kalapani & $12.44 \pm 0.14^{\mathrm{ef}}$ \\
Noonmati & $11.84 \pm 0.12^{\mathrm{ghi}}$ \\
\hline Means &
\end{tabular}

Means in a column bearing same superscript do not differ significantly $(p<0.01)$

present investigation, the TVC of milk samples in all the locations was quite higher than the maximum permissible limit as suggested by the European Union, which has been reported to be $4 \log _{10} \mathrm{cfu} / \mathrm{mL}$. In the present study, the standard plate count of raw milk samples collected in and around Guwahati was found to be higher as compared to the reports of numerous workers [16-20]. However, a low bacterial count (6.32 $\log _{10} \mathrm{cfu} / \mathrm{mL}$ ) was also reported [21] in raw milk in Guwahati as compared to the present study. Since the vendors who sell milk do not maintain the cold chains, there is every possibility for the microorganisms to grow and multiply in the milk as it provides a conducive environment, such as neutral $\mathrm{pH}$, high water activity, and excellent growth medium. Therefore, it can be presumed that such milk sold in and around Guwahati will have a very short shelf-life and might compromise with the food safety issues.

\section{Coliform count}

The mean \pm SE values of coliform counts of 200 raw milk samples collected from 25 different locations in and around Guwahati city are presented in Table-3. Analysis of variance revealed highly significant $(p<0.01)$ differences in coliform count among the different locations in and around Guwahati city. The highest count was recorded in both 6 mile and Panjabari areas $\left(7.50 \pm 0.07 \log _{10} \mathrm{cfu} / \mathrm{mL}\right)$ and was found to be highly significant from other locations, except Zoo Road Tiniali area $(7.32 \pm 0.10$ $\log _{10} \mathrm{cfu} / \mathrm{mL}$ ) which was numerically lower. Lowest coliform count was recorded in Maligaon area 
Table-3: Coliform count $\left(\log _{10} \mathrm{cfu} / \mathrm{mL}\right)$ of raw milk samples collected from different locations.

\begin{tabular}{lc}
\hline Locations & Mean \pm SE \\
\hline Zoo Road Tiniali & $7.32 \pm 0.10^{\mathrm{ab}}$ \\
Bamunimaidan & $6.59 \pm 0.05^{\mathrm{ghi}}$ \\
Bonda & $6.77 \pm 0.10^{\mathrm{fg}}$ \\
Maligaon & $6.34 \pm 0.05^{\mathrm{j}}$ \\
Panjabari & $7.50 \pm 0.07^{\mathrm{a}}$ \\
Eight mile & $7.08 \pm 0.08^{\mathrm{cd}}$ \\
Basistha & $6.46 \pm 0.05^{\mathrm{jj}}$ \\
Hatigaon & $7.04 \pm 0.08^{\mathrm{cd}}$ \\
Jalukbari & $6.62 \pm 0.09^{\mathrm{fghi}}$ \\
Jonali & $6.69 \pm 0.08^{\mathrm{fgh}}$ \\
Jorabat & $7.13 \pm 0.09^{\mathrm{bcd}}$ \\
Khanapara & $7.03 \pm 0.08^{\mathrm{cd}}$ \\
Kahilipara & $6.49 \pm 0.05^{\mathrm{hij}}$ \\
Mathghoria & $7.21 \pm 0.09^{\mathrm{bc}}$ \\
Ganeshguri & $6.49 \pm 0.06^{\mathrm{ij}}$ \\
Paltanbazar & $6.50 \pm 0.05^{\mathrm{hij}}$ \\
Ulubari & $6.59 \pm 0.06^{\mathrm{hhi}}$ \\
Bhetapara & $6.50 \pm 0.05^{\mathrm{hij}}$ \\
Satgaon & $6.44 \pm 0.05^{\mathrm{jj}}$ \\
Chandmari & $7.11 \pm 0.10^{\mathrm{cd}}$ \\
Panikhaiti & $7.07 \pm 0.09^{\mathrm{cd}}$ \\
Nine mile & $6.97 \pm 0.08^{\mathrm{de}}$ \\
Six mile & $7.50 \pm 0.07^{\mathrm{a}}$ \\
Kalapani & $6.39 \pm 0.04^{\mathrm{j}}$ \\
Noonmati & $6.82 \pm 0.08^{\mathrm{ef}}$ \\
\hline Means in column &
\end{tabular}

Means in a column bearing same superscript do not differ significantly $(p<0.01)$

$\left(6.34 \pm 0.046 \log _{10} \mathrm{cfu} / \mathrm{mL}\right)$ but did not differ significantly from Basistha $\left(6.46 \pm 0.05 \log _{10} \mathrm{cfu} / \mathrm{mL}\right)$, Kahilipara $\left(6.49 \pm 0.05 \quad \log _{10} \mathrm{cfu} / \mathrm{mL}\right)$, Ganeshguri $\left(6.49 \pm 0.06 \log _{10} \mathrm{cfu} / \mathrm{mL}\right)$, Paltanbazar $(6.50 \pm 0.05$ $\left.\log _{10} \mathrm{cfu} / \mathrm{mL}\right)$, Bhetapara $\left(6.50 \pm 0.05 \log _{10} \mathrm{cfu} / \mathrm{mL}\right)$, Satgaon $\left(6.44 \pm 0.05 \quad \log _{10} \mathrm{cfu} / \mathrm{mL}\right)$, and Kalapani $\left(6.39 \pm 0.04 \log _{10} \mathrm{cfu} / \mathrm{mL}\right)$ area although the coliform counts were numerically higher than Maligaon area. All the samples were found to be positive for gas production on inoculation in BGLB medium. The coliform count of the raw milk samples recorded in the present investigation was significantly higher than the maximum permissible standard. The present findings are in close agreement with the findings of an earlier report [22]. On the contrary, the coliform counts in the present investigation were significantly higher than some of the other reports [23-28]. This indicates selling of unhygienic milk in and around Guwahati. This might have attributed to the current observations on dirty udder conditions, unhygienic milking procedures and housing environment, contamination of milk with dung, dirty utensils, and improper drainage system maintained in the respective dairy farms, which need prioritizing interventions influencing the structure and development of unorganized private dairy sector.

\section{Conclusion}

Based on the findings of the present investigation, it could be concluded that there is a high risk of milk-borne illness among consumers due to inadequate farm-to-table practices. There is an utmost need to have a systematic awareness program with a follow-up mechanism to educate the dairy farmers on hygienic production practices at farm level to produce clean and wholesome milk as well as the retailers to promote maintenance of cold chain during the entire selling process.

\section{Authors' Contributions}

RAH, AT, and MR conceptualized and designed the work. SK carried out the experimentation. AT, RAH, MR, SKL, GKS, and ZH provided the necessary guidelines. SK, AT, RAH, and MR drafted the manuscript and all authors contributed critically to revise the manuscript. All authors have read and approved the final manuscript.

\section{Acknowledgments}

The authors would like to thank Assam Agricultural University, Assam, India, for providing all the necessary help and support to carry out the research work. The work was carried as a part of the Master's Degree program; therefore fund was utilized from the Departmental budget allocated for research by Assam Agricultural University.

\section{Competing Interests}

The authors declare that they have no competing interests.

\section{Publisher's Note}

Veterinary World remains neutral with regard to jurisdictional claims in published institutional affiliation.

\section{References}

1. Ramya, P., Swetha, C.S., Venkateswara, R.L., Tirupathi, R.E. and Jagadeeshbabu, A. (2015) Detection of adulterants in retail milk samples procured in Proddatur town, YSR Kadapa (DT), Andhra Pradesh. Int. J. Agric. Sci. Vet. Med., 3(1): 104-109.

2. Delgado, C.L. (2003) Rising consumption of meat and milk in developing countries has created a new food revolution. J. Nutr., 133(11 Suppl 2): 3907S-3910S.

3. Lindahl, J.F., Gill, J.P.S., Hazarika, R.A., Fairoze, N.M., Bedi, J.S., Dohoo, I., Chauhan, A.S., Grace, D. and Kakkar, M. (2019) Risk Factors for Brucella seroprevalence in peri-urban dairy farms in five Indian cities. Trop. Med. Infect. Dis., 4(70): 26-37.

4. Food and Agriculture Organization. (2013) Milk and Dairy Products in Human Nutrition. Food and Agriculture Organization, Rome, Italy. Available from: http://www. fao.org/docrep/018/i3396e/i3396e.pdf. Retrieved on 31-03-2016.

5. Mogessie, A. (1990) Microbiological quality of Ayib, a traditional Ethiopian cottage cheese. Int. J. Food Microbiol., 10(3-4): 263-268.

6. Boor, K.J., Brown, D.P., Murphy, S.C. and Bandler, D.K. (1998) Microbial and chemical quality of raw milk in New York state. J. Dairy Sci., 81(6): 1743-1748.

7. El Zubeir, I.E.M. and Ahmed, M.I.A. (2007) The hygienic quality of raw milk produced by some dairy farms in Khartoum state, Sudan. Res. J. Microbiol., 2(12): 988-991.

8. Hassan, A., Amjad, I. and Mahmood, S. (2009) Microbiological and physicochemical analysis of different UHT milk available in local market. Asian J. Food Agro 
Ind., 2(3): 434-447.

9. Marimuthu, M., Sankar, N., Sathish, A., Vivek, S. and Mohan, R.N. (2013) Comparative study on physicochemical quality of raw milk samples collected from different villages of Karur district, Tamil Nadu, India. Int. J. Pharm. Chem. Biol. Sci., 3(3): 635-638.

10. Food Safety and Standard Authority of India. (2015) Lab Manual of Methods of Analysis of Foods, Milk and Milk Products. Ministry of Health and Family Welfare, Government of India, New Delhi.

11. Memon, M.A. (2000) Physico-chemical and Hygienic Quality of Milk Supplied to the Canteens of Various Hospitals in Hyderabad City, Pakistan, M.V.Sc. Thesis, Sindh Agriculture University, Tandojam, Pakistan.

12. Gran, H.M., Mutukumira, A.N., Wetlesen, A. and Narvhus, J.A. (2002) Smallholder dairy processing in Zimbabwe: Hygienic practices during milking and the microbiological quality of the milk at the farm and on delivery. J. Food Control, 13(1): 41-47.

13. Gilani, I. (2008) Milk Provided to City Unfit for Humans. Available from: http://www.nation.com.pk/pakistan-newsnewspaper-daily-englishonline/Regional/Lahore/01Ju1-2008/Milkprovided-to-City-unfit-for-humans. Retrieved on 31-03-2016.

14. Nirwal, S., Pant, R. and Rai, N. (2013). Analysis of milk quality, adulteration and mastitis in milk samples collected from different regions of Dehradun. Int. J. Pharm. Tech. Res., 5(2): 359-364.

15. Faraz, A., Lateef, M., Mustafa, M.I., Akhtar, P., Yaqoob, M. and Rehman, S. (2013) Detection of adulteration, chemical composition and hygienic status of milk supplied to various canteens of educational institutes and public places in Faisalabad. J. Anim. Plant Sci., 23(Suppl 1): 119-124.

16. Mwangi, A., Arimi, S.M., Mbugua, S., Kangethe, E.K. and Omore, A.O. (2000) Assurance of Marketed Milk Quality in Kenya. Compendium of Biennial Scientific Conference, Kenya. p30-31.

17. Fakudze, F.M. and Dlamini, A.M. (2001) Compositional and hygienic quality of consumer milk from shops in
Swaziland. UNISWA Res. J. Agri. Sci. Tech., 5(2): 169-176.

18. Shitandi, A. and Kihumbu, G. (2004) Assessment of the California mastitis test usage in smallholder dairy herds and risk of volatile antimicrobial residues. J. Vet. Sci., 5(1): 5-9.

19. Srinu, B., Kumar, A.V., Kumar, M.S., Narayana, B.V.L. and Rao, T.M. (2012) Assessment of microbiological quality and associated health risks of raw milk sold in and around Hyderabad city. Int. J. Pharm. Bio. Sci., 3(4): 609-614.

20. Kunda, B., Pandey, G.S. and Muma, J.B. (2015) Compositional and sanitary quality of raw milk produced by smallholder dairy farmers in Lusaka Province of Zambia. Livest. Res. Rural Dev., 27(10): 201.

21. Dinki, N. and Balcha, E. (2013) Detection of antibiotic residues and determination of microbial quality of raw milk from milk collection centres. Adv. Anim. J. Vet. Sci., 1(3): 80-83.

22. Edward, K.C. and Inya, I.M. (2013) The Microbial quality of raw milk from four locations in Abia state, Nigeria. $J$. Pharm. Biol. Sci., 5(3): 30-33.

23. Mutukumira, A.N., Feresu, S.B., Narbhus, J.A. and Abrahamsen, R.K. (1996) Chemical and microbiological quality of raw milk produced by smallholder farmers in Zimbabwe. J. Food Prot., 59(9): 984-987.

24. Saitanu, I.A., Chuanchuen, K.R., Nuanuarsuwan, S., Koowatananukul, C. and Rugkhaw, V. (1996) Microbiological quality of raw cow milk. Thai. J. Vet. Med., 26(3): 193-214.

25. Kalilur, M., Khan, R. and Malik, A. (2002) Microbiological quality of milk, vegetable and fruit juice. J. Food Sci. Tech., 39(2): 120-123.

26. Ali, A.A. (2010) Microbiological safety of raw milk in Khartoum State, Sudan:2-Khartoum-North city. Pak. J. Nut., 9(7): 651-653.

27. Belbachir, C., Khamri, M. and Saalaoui, E. (2015) Microbiological quality of the raw cow milk at three rural communes of the Eastern region of Morocco. Int. Food Res. $J ., 22(4):$ 1675-1680.

28. Nanu, E., Sunil, B., Pretjit, T.M. and Latha, C. (2006) Consumer perception on quality of liquid milk in Kerala. $J$. Vet. Public Health, 5(1): 49-51. 